\title{
TATA BAHASA FUNGSIONAL (FUNCTIONAL GRAMMAR)
}

\author{
Felta Lafamane \\ feltafamane@gmail.com
}

\begin{abstract}
Abstrak
Fungsionalisme dalam kajian linguistik merupakan pengaruh dari beberapa paham dalam ilmu seperti antropologi, sosiologi dan psikologi. Paham yang ada disekitar kemunculan fungsionalisme sebagai akarnya adalah strukturalis meskipun ada yang berpendapat berbeda tentang hal ini. Linguistik fungsional dipelopori oleh Roman Jakobson dan Andre Martinet, kehadirannya sangat berarti dalam upaya menjembatani kesenjangan antara linguistik struktural Amerika dan Eropa. Fungsionalisme adalah gerakan dalam linguistik yang berusaha menjelaskan fenomena bahasa dengan segala manifestasinya dan beranggapan bahwa mekanisme bahasa dijelaskan dengan konsekuensi-konsekuensi yang ada kemudian dari mekanisme itu sendiri. Secara umum tata bahasa fungsional adalah teori yang berusaha menjelaskan susunan bahasa alamiah dari segi fungsionalitasnya. Pengembangan teoriteori TBF harus memenuhi tiga standar: Kecukupan tipologis, Kecukupan pragmatis, Kecukupan psikologis. Dalam TBF ada tiga tingkatan fungsi yang menjadi pokok perhatian, yaitu: Fungsi Semantik (Pelaku [Agent], Pasien [Patient], Penerima [Recipient], dsb.). Fungsi Sintaktik (Subjek, predikat dan Objek). Fungsi Pragmatik (Tema dan Ekor [Tail], Topik dan Fokus). Kemudian penerapan fungsi bahasa menurut Jakobson dapat kita aplikasikan dalam analisis wacana baik berupa teks maupun non-teks. Penerapan aliran fungsional dalam bahasa Indonesia tidak sepenuhnya dapat diterima. Selain adanya konsep bahasa yang berbeda, namun juga sulit mencari padanan istilah dalam bahasa Indonesia. Namun demikian aliran ini sangat mempengaruhi dalam perkembangan tata bahasa bahasa Indonesia.
\end{abstract}

Keyword:tata bahasa, fungsional, struktur kalimat

\section{Abstract}

Functionalism in the study of linguistics is the influence of several understandings in science such as anthropology, sociology and psychology. The understanding that surrounds the emergence of functionalism as its root is structuralist although there are different opinions about this. Functional linguistics pioneered by Roman Jakobson and Andre Martinet, his presence is very meaningful in an effort to bridge the gap between structural linguistics of America and Europe. Functionalism is a movement in linguistics that seeks to explain the phenomenon of language with all its manifestations and assumes that the mechanism of language is explained by the consequences that follow from the mechanism itself. In general functional grammar is a theory that attempts to explain the natural language structure in terms of functionality. The development of TBF theories must meet three standards: Typological sufficiency, pragmatic sufficiency, psychological sufficiency. In TBF there are three levels of functions that are of concern, namely: Semantic Functions (Actors, Patients, Recipients, etc.). Syntactic Functions (Subject, predicate and Object). Pragmatic Functions (Themes and Tails, Topics and Focus). Then the application of language functions according to Jakobson can be applied in discourse analysis in the form of texts and non-texts. The application of functional flow in Indonesian is not entirely acceptable. In addition to the different language concepts, it is also difficult to find an equivalent term in Indonesian. However, this flow is very influential in the development of Indonesian language grammar.

Keyword: grammar, functional, sentence structure 


\section{PENDAHULUAN}

Aliran-aliran yang berkembang pada ranah linguistik sangatlah dipengaruhi oleh bidang ilmu lain dan paham-paham yang ada disekitarnya, terutama yang serumpun dalam ilmu-ilmu sosial dan humaniora. Linguistik dewasa ini berkembang dengan pesat. Perkembangan tersebut dapat dilihat dari kian banyaknya teori dan penelitian yang telah dihasilkan serta munculnya bermacam gerakan dan aliran. Perkembangan teori-teori tersebut merata pada pelbagai cabang-cabang linguistik, seperti pada fonetik, fonologi, morfologi, sintaksis, semantik, juga pragmatik. Bukan itu saja, penelitian-penelitian yang dilahirkan dari perkembangan teori tersebut pula semarak dan tumbuh bak jamur di musim hujan. Perkembangan teori dan makin banyaknya penelitian yang dihasilkan itu tidak terlepas dari gerakan dan aliran yang memayungi dan menyemarakkan dunia linguistik. Dalam linguistik terdapat aliran-aliran seperti aliran linguistik tradisional, struktural, transformasional, fungsional dan masih banyak lagi. Fungsionalisme dalam kajian linguistik merupakan pengaruh dari beberapa paham dalam ilmu seperti antropologi, sosiologi dan psikologi. Paham yang ada disekitar kemunculan fungsionalisme sebagai akarnya adalah strukturalis meskipun ada yang berpendapat berbeda tentang hal ini. Dalam ilmu antropologi, fase perkembangannya lebih dahulu kemunculan fungsionalisme dari pada strukturalisme itu sendiri. Akan tetapi untuk bidang linguistik, strukturalisme merupakan akar dari kemunculan fungsionalisme atau struktural fungsional, yang kemudian Halliday menyebutnya dengan Linguistik Struktural Fungsional (SFL) atau Linguistik Fungsional Sistemik.

Linguistik strukturalis berusaha mendeskripsikan suatu bahasa berdasarkan ciri yang dimiliki bahasa itu. Pandangan ini adalah sebagai akibat dari konsep-konsep atau pandangan-pandangan baru terhadap bahasa yang dikemukakan oleh Bapak Linguistik Modern, yaitu Ferdinand de Saussure (Chaer,2003:346). Linguistik ini juga masih terdapat kelemahan-kelemahan seperti Bidang morfologi dan sintaksis dipisahkan secara tegas, metode drill and practice sangat memerlukan ketekunan dan kesabaran serta sangat menjemukan, proses berbahasa merupakan proses rangsang-tanggap berlangsung secara fisis dan mekanis padahal manusia bukan mesin, kegramatikalan berdasarkan kriteria keumuman suatu kaidah yang salah pun bisa benar jika dianggap umum, faktor historis sama sekali tidak diperhitungkan dalam analisis bahasa dan objek kajian terbatas sampai level kalimat tidak menyentuh aspek komunikasi.

Contoh: Bisa ambilkan buku itu? (dilihat dari bentuknya berupa kontruksi introgatif, dari segi fungsinya kalimat itu dapat digunakan untuk menanyakan tentang kemampuan (bisa tidaknya) orang yang diajak bicara).

Fungsionalisme merupakan percabangan dari strukturalisme. Bertolak dari masih adanya sedikit kelemahan linguistik strukturalis, maka lahirlah teori linguistik fungsional yang menampilkan tingkat kesempurnaan dibandingkan dengan teori sebelumnya meskipun masih didapatkan sedikit titik kelemahan dalam teori ini, namun teori linguistik fungsional ini telah berhasil melihat setiap komponen bahasa berdasarkan fungsi dan menginspirasi gagasan adanya relasi antara struktur dan fungsi bahasa.

\section{PEMBAHASAN}

\section{A. Pandangan Teori Linguistik Fungsional}


Linguistik fungsional dipelopori oleh Roman Jakobson dan Andre Martinet, kehadirannya sangat berarti dalam upaya menjembatani kesenjangan antara linguistik struktural Amerika dan Eropa. Linguistik struktural (Eropa) banyak dipengaruhi oleh gagasan fungsi-fungsi linguistik yang menjadi ciri khas aliran Praha. Trubeckoj terkenal mengembangkan metode-metode deskripsi fonologi, maka R. Jakobson terkenal karena telah menyatakan dengan pasti pentingnya fonologi diakronis yang mengkaji kembali dikotomi-dikotomi Ferdinand de Saussure antara lain dikotomi yang memisahkan dengan tegas sinkronis dan diakronis.

Andre Martinet banyak mengembangkan teori-teori aliran Praha. Dengan tulisannya tentang netralisasi dan segmentasi. Pikiran-pikirannya telah memperkaya dan mengembangkan studi linguistik, terutama fonologi deskriptif, fonologi diakronis, sintaksis, dan linguistik umum, disamping ia menerapkan metode dan linguistik modern dengan menaruh perhatian yang luar biasa pada kenyataan bahasa aktual.

Gagasan Jakobson merupakan pengembangan dari pemikiran-pemikiran aliran Praha. Selain fungsi linguistik sebagai ciri khas sekolah Praha, ia juga menyoroti fungsi-fungsi unsur tertentu dan fungsifungsi aktivitas linguistik itu sendiri. Jakobson memandang suatu tindak linguistik dari enam sudut, yaitu (1) dalam hubungan dengan pembicara, (2) pendengar, (3) konteks, (4) kontak, (5) kode, dan (6) pesan.

Jakobson menyejajarkan enam faktor bahasa dengan enam fungsi bahasa. Enam faktor bahasa itu dipandang dari sudut pembicara, pendengar, konteks, pesan, hubungan, dan kode. Sejajar dengan enam faktor bahasa ini, Jakobson mengatakan ada enam fungsi bahasa, yakni ekspresif, konatif, denotatif, fatik, metalinguistik, dan puitik.

Enam faktor bahasa dan enam fungsi bahasa ini saling berkaitan;

\begin{tabular}{|l|l|}
\hline Faktor Bahasa & Fungsi Bahasa \\
\hline Pembicaraan & Ekspresif \\
\hline Pendengar & Konatif \\
\hline Konteks & Denotatif/referensi \\
\hline Hubungan & Fatik \\
\hline Kode & Metalingual \\
\hline Pesan & Puitik \\
\hline
\end{tabular}

Keterangan tabel:

1. Ekspresif, berpusat pada pembicara, yang ditujukan oleh interjeksi-interjeksi;

2. Konatif, berpusat pada pendengar, yang ditujukan oleh vokatif dan imperative;

3. Denotative, berpusat pada konteks, yang ditujukan oleh pernyataan-pernyataan faktual, dalam pelaku ketiga, dan dalam suasana hati indikatif; 
4. Phatic, berpusat pada kontak, yang ditujukan oleh adanya jalur yang tidak terputus antara pembicara dan pendengar. Misalnya, dalam pembicaraan melalui telefon, kata-kata 'hello, ya..ya..., heeh' yang dipergunakan untuk membuat jelas bahwa seseorang masih mendengarkan dan menunjukan jalur percakapan tidak terputus;

5. Metalinguistik, berpusat pada kode; yang berupa bahasa pengantar ilmu pengetahuan, biasanya berisi rumus-rumus atau lambang-lambang tertentu;

6. Puitis, berpusat pada pesan.

Fungsionalisme adalah gerakan linguistik yang beranggapan bahwa struktur fonologis, grammatikal dan semantik ditentukan oleh fungsi yang dijalankannya dalam masyarakat, bahwa bahasa itu sendiri mempunyai fungsi yang beraneka ragam. Gerakan ini merupakan percabangan dari strukruralisme dan menentang intelektualisme di Eropa yang beranggapan bahwa bahasa hanyalah sekedara ungkapan. (Kamus Linguistik: 2008).

Fungsionalisme juga merupakan gerakan dalam linguistik yang berusaha menjelaskan fenomena bahasa dengan segala manifestasinya dan beranggapan bahwa mekanisme bahasa dijelaskan dengan konseuensi-konsekuensi yang ada kemudian dari mekanisme itu sendiri. Wujud bahasa sebagai sistem komunikasi manusia tidak dapat dipisahkan dari tujuan berbahasa, sadar atau tidak sadar.

Konsep utama dalam fungsionalisme ialah fungsi bahasa dan fungsi dalam bahasa. Menyangkut yang pertama sikap fungsionalistis sebagai berikut.

1. Analisis bahasa mulai dari fungsi ke bentuk.

2. Sudut pandang pembicara menjadi perspektif analisis.

3. Deskripsi yang sistematis dan menyeluruh tentang hubungan antara fungsi dan bentuk.

4. Pemahaman atas kemampuan komunikatif sebagai tujuan analisis bahasa.

5. Perhatian yang cukup pada bidang interdisipliner, misalnya sosiolinguistik dan penerapan linguistik pada masalah praktis, misalnya pembinaan bahasa.

Selanjutnya gagasan dan pandangan Jakobson lain adalah telaah tentang aphasia dan bahasa kanakkanak. Aphasia yang dimaksud adalah gejala kehilangan kemampuan menggunakan bahasa lisan baik sebagian maupun seluruhnya, sebagai akibat perkembangan yang salah. Gangguan afasik dapat dikelompokkan menjadi dua, yakni:

1. Similarity disorders, yang mempengaruhi seleksi dan subtitusi item, dengan stabilitas kombinasi dan konsstektur yang bersifat relatif.

2. Contiguity disorders, yang seleksi dan subtitusinya secara relatif normal sedangkan kombinasi rusak dan tidak gramatikal, urutan kata kacau, hilangnya infleksi dan preposisi, konjungsi, dan sebagainya. 
Jakobson juga menekankan pentingnya korelasi-korelasi fonologis sebagai seuntai perbedaanperbedaan arti yang terpisah. Menurut buku Jakobson dan Halle Fundamentals of Language, 1956, menyatakan ciri-ciri expressive, configurative, dan distinctive:

1. Expressive, meletakan tekanan pada bagian ujaran yang berbeda atau pada ujaran yang berbeda; menyarankan sikap emosi pembicara;

2. Configurative, menandai bagian ujaran ke dalam satuan-satuan gramatikal, dengan memisahkan ciri kulminatif satu persatu, atau dengan memisahkan membatasinya (ciri-ciri demarkatif);

3. Distinctive, bertindak untuk memperinci satuan-satuan linguistik, dimana ciri-ciri itu terjadi secara serempak dalam untaian, yang berujud fonem. Fonem-fonem dirangkaikan ke dalam urutan; pola dasar urutan serupa itu berujud suku kata. Dalam setiap suku kata terdapat bagian yang lebih nyaring yang berupa puncak. Bila puncak itu berisi dua fonem atau lebih, maka salah satu daripadanya adalah puncak fonem atau puncak suku kata.

Tokoh lain dalam linguistik fungsional adalah Andre Maertinet, ia juga mengembangkan teori-teori Sekolah Praha. Pikiran-pikiran Martinet mengenai fonologi deskriptif, fonologi diakronis, sintaksis, dan linguistik umum merupakan sumbangan pemikiran bagi linguistik modern. Fonologi sebagai fonetik fungsional harus berdasarkan fakta-fakta dasar atau mengetahui fungsi-fungsi perbedaan bunyi bahasa sebagaimana mestinya.

Martinet mencurahkan perhatian pada fonologi diakronis, dengan mencoba membuat deskripsi murni, dimana fonologisasi dan defonologisasi direkam, disertai keterangan tentang perubahan-perubahan menurut prinsip-prinsip umum. Kriterium interpretasi dasar diberikan oleh dua unsur yang berlawanan: (1) efisiensi dalam komunikasi, dan (2) tendensi pada upaya yang minimum. la juga menyatakan analisis fonem ke dalam ciri-ciri distingtif mengungkapkan adanya korelasi-korelasi, dimana sebuah fonem yang terintegrasi dalam untaian korelatif akan menjadi stabil. la telah mengembangkan gagasan artikulasi rangkap yang menarik. Ucapan bahasa pertama-tama melalui suatu artikulasi dalam monem-monem yang berupa unit-unit dasar gramatis yang oleh para linguis Amerika disebut morphem. Sejumlah ujaran yang tak terbatas dapat diidentifikasikan oleh monem-monem yang terbatas jumlahnya. Setiap artikulasi melibatkan ekspresi dan isi. Monem adalah satuan dwimuka: ekpresi dan isi. Bagi Martinet, konsep dasar analisis fonologi yaitu fonem sedangkan bagi Jakobson yaitu ciri distingtif.

Martinet juga menerapkan wawasan fungsionalnya pada sintaksis, dan telah mensintesakan teoriteorinya itu dalam tulisan-tulisan yang ringkas dan seimbang: Elements of General Linguistics, dan A Functional View of Language. Didalam karya tersebut dirumuskan dengan jelas perbedaan antara (i) monem fungsional, seperti preposisi, kasus akhiran, yang konetif dan centrifugal yang menunjukkan adanya hubungan diantara satu unsur dengan bagian ujaran; dan (ii) monem pengubah, seperti satuan gramatikal artikel yang centripetal; nilai tunggal atau jamak dan unsur-unsur yang dibutuhkan.

Martinet juga menggarisbawahi juga fungsi sintaksis sebagai gagasan yang sentral. Gagasannya ini berupa kelanjutan wawasan fungsional yang telah disarankan oleh Sekolah Praha. Fungsi-fungsi bahasa dan fungsi-fungsi unsur linguistik sebagai suatu sistem unsur-unsur atau struktur unsur-unsur, dipelajari 
untuk menjelaskan perbedaan bahasa dengan sistem tanda buatan yang mungkin distrukturkan dalam suatu cara yang sama tetapi tak dapat memiliki fungsi-fungsi yang sama seperti bahasa. Bagaimanapun pandangan struktural itu dapat dirujukkan kembali dengan pandangan fungsional, meskipun hal itu bagi Martinet adalah pelengkap logisnya. Pilihan nama fungsional sebagai pengganti struktural, menunjukkan bahwa aspek fungsional adalah paling membuka pikiran, dan bahwa hal itu tidak mesti dipelajari secara terpisah dari yang lain.

Linguistik Fungsional merupakan gerakan linguistik yang beranggapan bahwa struktur fonologis, gramatikal dan semantic ditentukan oleh fungsi yang dijalankan oleh masyarakat dan bahwa bahasa itu sendiri memfunyai fungsi yang beraneka ragam. Kridalaksana (2008:68)

Adapun ciri utama teori linguistik fungsional adalah:

1. Teori ini memberi tempat kepada tiga lapisan fungsi, yakni fungsi semantik: pelaku, tujuan, penerima dan seterusnya. Fungsi sintaksis: subjek, predikat, objek, dan pelengkap. Fungsi pragmatik: tema dan ekor, topik dan fokus.

2. Tidak mengenal transformasi, filter, dekomposisi leksikal

3. Deskripsi ungkapan bahasa dimulai dengan pembentukan predikasi dasar yang dilakukan dengan penyisipan ungkapan ke dalam kerangka predikat.

4. Pengungkapan bahasa berjalan dari semantik ke sintaktis terus ke pragmatik dan berakhir pada apa yang disebutnya ezpression rules.

\section{B. Kelebihan dan Kelemahan Teori Linguistik Fungsional}

\section{Kelebihan Teori Linguistik Fungsional}

Pada khasanah kebahasaan, bila memahami gagasan dan pandangan linguistik Fungsional, maka aliran ini sangat mempengaruhi tata bahasa dalam khasanah perkembangan linguistik sebelumnya, sekaligus membuka cakrawala baru agar aspek fungsional menjadi pertimbangan penelitian bahasa. Dengan menelaah istilah fungsional, praktis landasan yang digunakan dalam melihat bahasa berdasarkan fungsi, khususnya tataran fonologi, morfem, dan sintaksis. Keunggulan aliran ini adalah kita dapat mengetahui bahwa setiap fonem (bunyi) itu memiliki fungsi, sehingga dapat membedakan arti. Setiap monem (istilah Martinet) yang diartikulasikan memiliki isi dan ekspresi, dengan begitu dapat dilihat fungsinya. Kemudian pada tataran yang lebih besar yaitu sintaksis, aliran ini menekankan pada fungsi preposisi dan struktur kalimat, maksudnya unsur linguistik dalam sebuah kalimat dapat dijelaskan dengan merujuk pada fungsi sehingga ditemukan pemahaman logis yang utuh. Jadi, aliran ini telah berhasil melihat setiap komponen bahasa berdasarkan fungsi dan menginspirasi gagasan adanya relasi antara struktur dan fungsi bahasa. 


\section{Kelemahan Teori Linguistik Fungsional}

Dalam kebahasaan, aliran ini tentunya memiliki beberapa titik lemah, diantaranya gagasan fungsional tidak menyentuh secara mendalam komponen fungsional untuk menentukan makna dalam penelitian bahasa, seperti pada tataran sintaksis hanya menyebutkan adanya fungsi dalam setiap struktur bahasa, namun tidak menjelaskan terminologi apa saja yang tercakup di dalamnya. Selanjutnya, bagaimana menyusun kalimat yang benar, berdasarkan fungsi pun tidak jelas. Demikian halnya pada tataran fonologi dan morfologi. Jadi, kelemahan aliran ini adalah tidak mampu menguraikan fungsi unsur linguistik lebih rinci, khsususnya pada tataran sintaksis. Dalam struktur kalimat, gagasan aliran ini tidak menjelaskan komponen apa saja yang tercakup dalam aspek fungsional pada kalimat. Sebagaimana kita ketahui ada fungsi lain dalam kalimat yaitu fungsi semantis dan fungsi pragmatis.

\section{Aplikasi Linguistik Fungsional dalam Bahasa Indonesia}

Satu hal yang masih mengganjal dalam pikiran kita tentang pengaplikasian aliran ini dalam bahasa Indonesia? Ketika berbicara fungsi maka kita harus memahami konsep fungsi dalam bahasa Inggris dan bahasa Indonesia. Bisa jadi konsep yang ditawarkan oleh aliran ini tidak dapat diserap dalam semua bentuk, struktur dan fungsi sesungguhnya dalam bahasa Indonesia. Sebagian kita dapat memperhatikan contoh berikut ini:

Contoh Fonologi:

$<$ baku $>/ \mathrm{b} /, \mathrm{a} /, / \mathrm{k} /, \mathrm{u} /$

$<$ paku $>/ \mathrm{p} /, \mathrm{a} /, / \mathrm{k} /, / \mathrm{u} /$

Contoh Morfologi:

Meng- + tulis

PeN- + tulis

Contoh Sintaksis:

Letusan Gunung Merapi itu telah menewaskan 200 orang.

1. Jika dilihat dari contoh fonologi, penggunaan fonem /b/pada kata $<$ baku $>$ dan $/ p /$ pada $<$ paku $>$ tidak mempunyai makna. Namun karena diposisikan bersama sebagai pasangan minimal (minimal pairs), dimana keduanya daerah artikulasi yang sama yakni bilabial, maka penggunaan fonem /b/ dan /p/ menjadi memiliki fungsi pembeda makna.

2. Dari aspek morfologi dapat dilihat contoh penggunaan awalan Meng- dan PeN-. Awalan me-tulis dan pe-tulis memiliki fungsi pembeda. Meng- + tulis menjadi 'menulis' sebagai kata kerja dan peN- tulis menjadi 'penulis'. Penggunaan morfem bebas atau kata dasar yang sama namun didahului oleh morfem terikat yang berbeda maka fungsinya pun menjadi berbeda. 
3. Selanjutnya dari tataran sintaksis, kalimat tersebut memiliki struktur yang benar. Jika disegmentasikan kalimat itu menjadi /letusan gunung Merapi/, /menewaskan/, dan /200 orang/. Pemenggalan struktur kalimat dilakukan berdasarkan fungsi masing-masing unsur.

Kemudian penerapan fungsi bahasa menurut Jakobson dapat kita aplikasikan dalam analisis wacana baik berupa teks maupun non-teks. Penerapan aliran fungsional dalam bahasa Indonesia tidak sepenuhnya dapat diterima. Selain adanya konsep bahasa yang berbeda, namun juga sulit mencari padanan istilah dalam bahasa Indonesia. Namun demikian aliran ini sangat mempengaruhi dalam perkembangan tata bahasa bahasa Indonesia. Dengan mengenal fungsional maka kita mengetahui fungsi bahasa bukan hanya sebagai sistem 'langue' (istilah Saussure), tetapi juga dalam bentuk tuturan 'parole'.

Dalam ranah kesusasteraan, enam fungsi bahasa dapat dimanfaatkan untuk menelaah karya sastra. Model komunikasi sastra yang lebih dikenal dengan model komunikasi Jakobson dapat digunakan dalam kajian, puisi, novel, drama, dan hal lain yang menggunakan bahasa. Jadi, sebagai pijakan awal dalam mengkaji bahasa baik dalam sastra mapun linguistik, enam fungsi bahasa dapat diterapkan dalam analisis bahasa Indonesia. Kendati demikian, sangat diperlukan adanya pengembangan konsep dan gagasan yang dapat menjawab problematika kebahasaan secara tuntas.

\section{Tata Bahasa Fungsional (Functional Grammar)}

Tata bahasa fungsional (functional grammar) sebenarnya adalah nama sekumpulan teori linguistic yang secara umum dapat digolongkan ke dalam linguistik fungsional (linguistic functionalism), termasuk didalamnya functional discourse grammar yang dikembangkan oleh linguis belanda simon dik dan systemic functional grammar yang dikembangkan oleh linguis inggris Michael A.K. Halliday

Tata bahasa fungsional adalah lebih dikenal dengan systemic functional grammar adalah teori penggunaan bahasa yang menitikberatkan analisis bahasa pada penyampaian informasi, baik dalam bentuk lisan maupun tulisan sebagaimana yang dijelaskan Halliday dalam bukunya yang berjudul An Introductional to Functional Grammar (1985: xiii) "Functional Grammar is one that contrues all the units of a language its clause, phrases and so on -as organic configurations of function " "Berdasarkan teori diketahui bahwa Halliday bahasa fungsional adalah sistem yang menafsirkan semua unit bahasa, klausanya, frasanya dan unit bahasa lainnya sebagai konfigurasi fungsi yang organis.

Tiga fungsi makna yang perlu kita ketahui yaitu:

a. Kita menggunakan bahasa untuk membicarakan tentang pengalaman dalam dunia kita, memasukan dunia kita untuk mendapatkan sebuah pikiran, menggambarkan secara tepat dan keadaan wujud meliputi hal itu.

b. Kita juga menggunakan bahasa untuk berinteraksi dengan orang lain

c. Menggunakan bahasa untuk mengorgnisir pesan kita kepada orang lain

Secara spesifik fungsi dapat ditentukan dslam atu atau yang lainnya dalam tiga fungsi secara garis besar yaitu dalam fungsi-fungsi besar metafungsi: 

a. Experiential
b. Interpersonal
c. Textual

Secara umum tata bahasa fungsional adalah teori yang berusaha menjelaskan susunan bahasa alamiah dari segi fungsionalitasnya. Karena hal itulah maka pengembangan teori ini memusatkan perhatiannya pada tiga hal yang saling berkait yaitu:

1. Fungsionalitas bahasa ilmiah

2. Fungsionalitas relasi yang terjadi pada berbagai tingkatan susunan tata bahasa

3. Sasaran yang ingin dicapai yaitu keterpakaian teori ini sebagai alat analisis atas berbagai aspek bahasa dan pemakaian bahasa.

Untuk merealisasikan hal-hal di atas pengembangan teori-teori TBF harus memenuhi tiga standar:

\section{Kecukupan tipologis}

Artinya, aturan dan prinsip-prinsip teori ini harus dapat diterapkan dalam bahasa alamiah manapun

\section{Kecukupan pragmatis}

Artinya, rumusan apapun yang dikemukakan oleh teori ini harus dapat memberikan pemahaman mengenai bagaimana ungkapan-ungkapan kebahasaan dapat secara efektif dipakai dalam interaksi komunikatif.

\section{Kecukupan psikologis}

Artinya, apapun yang dikemukakan oleh TBF harus sesuai dengan hal-hal yang telah diketahui mengenai mekanisme pemrosesan psikologis yang terjadi dalam pemakaian bahasa alamiah.

Karena gagasan mengenai fungsionalitas menempati posisi yang sangat penting dalam TBF maka aturan dan prinsip-prinsip TBF dirumuskan dalam terma-terma fungsional. Dalam TBF ada tiga tingkatan fungsi yang menjadi pokok perhatian, yaitu:

1. Fungsi Semantik (Pelaku [Agent], Pasien [Patient], Penerima [Recipient], dsb.). Fungsi ini mendefinisikan peranan yang dimainkan oleh peserta dalam suatu peristiwa atau perbuatan sebagaimana ditunjukkan oleh predikat.

2. Fungsi Sintaktik (Subjek predikat dsb.). Fungsi ini mendefinisikan bagaimana sudut pandang suatu peristiwa atau perbuatan diwujudkan dalam ungkapan-ungkapan kebahasaan.

3. Fungsi Pragmatik (Tema dan Ekor [Tail], Topik dan Fokus). Fungsi ini mendefinisikan status informasi konstituen ungkapan-ungkapan kebahasaan dan menghubungkan ungkapan-ungkapan yang 
ada dalam diskursus/wacana yang sedang berlangsung itu dengan status Pengujar (Speaker) dan Penerima Ujaran (Addressee) dalam interaksi verbal yang sedang berlangsung.

Penjelasan contoh-contoh berikut diharapkan menjadi sebuah pembenaran paham tata bahasa fungsional bahwa, analisis sebuah bahasa haruslah melibatkan semua tataran fungsi (sintaksis, semantik, dan pragmatik).

Salah satu fungsi sintaksis, yaitu subjek diberi banyak batasan yang di antaranya:

(i) Subjek adalah konstituen yang mengacu kepada persona pelaku

(ii) Subjek adalah konstituen yang berkongruen dengan tempat verba itu berkongruen.

(iii) Subjek adalah konstituen yang mengacu kepada sesuatu yang diceritakan oleh kalimat (atau oleh predikat).

Definisi-definisi subjek tersebut kita terapkan pada contoh kalimat berikut:

(1) Andre Hirata mengarang buku Laskar Pelangi.

(2) Buku Laskar Pelangi dikarang oleh Andre Hirata.

(3) Dengan kejujuran Andre Hirata telah mengarang buku Laskar Pelangi.

(4) Dengan kejujuran inilah oleh Andre Hirata telah dikarang buku Laskar Pelangi.

Penjelasan:

Subjek kalimat (1) berkorelasi dengan definisi subjek (i), (ii), dan (iii).

Subjek kalimat (2) berkorelasi dengan definisi subjek (ii), dan (iii).

Subjek kalimat (3) berkorelasi dengan definisi subjek (i), dan (ii).

Pada kalimat (4), (i) dapat diterapkan pada Andre Hirata, (ii) pada buku Laskar Pelangi, dan (iii) pada unsur kejujuran inilah. Jadi, (i), (ii), dan (iii) tidak berarti tunggal terhadap fungsi subjek. Oleh karena itu, definisi-definisi seperti itu lebih tepat dibedakan sebagai (i) subjek logis, (ii) subjek tata bahasa, dan (iii) subjek psikologi. Dapat kita lihat bahwa fungsi-fungsi dapat relevan pada berbagai tingkat dalam struktur tata bahasa. Korelasi uaraian definisi subjek (i), (ii), dan (iii) di atas yang diterapkan pada contoh-contoh kalimat (1), (2), (3) yang kemudian menurunkan (i) sebagai (i) subjek logis, (ii) subjek tata bahasa, dan (iii) subjek psikologi yang menegaskan bahwa berbagai macam fungsi harus saling dibedakan maka fungsi sintaksis, fungsi semantik, dan fungsi pragmatik sangatlah relevan untuk dijadikan payung analisis.

\section{Fungsi Sintaksis}

Analisis fungsi sintaksis meliputi subjek, predikat, objek, pelengkap, keterangan. 
(1) Andre Hirata/ mengarang/ buku Laskar Pelangi/ dengan kejujuran.

$$
\text { S P } \quad \mathrm{O} \quad \mathrm{K}
$$

Tampak bahwa analisis fungsi sintaksis hanya membicarakan segmen kelas kata yang menduduki fungsi sintaksis masing-masing.

2. Fungsi Semantik

Analisis fungsi semantik meliputi agens, pasiens, instrument

(1) Andre Hirata / mengarang/ buku Laskar Pelangi/ dengan kejujuran.

Agens + aksi + pasiens + instrument

Begitupun fungsi semantik sebagai kelanjutan analisis fungsi semantik hanya menambahkan analisis fungsi sintaksis dengan istilah yang berkaitan dengan struktur makna.

\section{Fungsi Pragmatik}

Fungsi pragmatik secara tradisional dinamai subjek psikologis dan predikat psikologi yang sebelumnya sering diuraikan 'apa yang diceritakan oleh kalimat', 'serta apa yang diceritakan tentang itu'. Seperti yang tampak pada contoh kalimat (1) - (4) yang telah diuraikan di atas tadi, bahwa subjek psikologis tidak selalu bertepatan sebagai subjek sintaksis. Misalnya, subjek sintaksis pada (4), yaitu buku Laskar Pelangi yang padahal kalimat ini menerangkan sesuatu tentang apa-apa yang ditegaskan oleh unsur kejujuran.

Oleh sebab itulah, untuk menegaskan subjek dan predikat psikologis dari subjek dan predikat sintaksis digunakan dengan istilah topic dan commen (topik dan sebutan) atau dengan istilah thema dan rhema. Hubungan thema dan rhema banyak bersangkutan dengan sistematika penggunaan bahasa berupa ketentuan-ketentuan penggunaan bahasa dalam interaksi sosial. Oleh sebab itulah fungsi tersebut dikatakan fungsi pragmatik. Kedudukan pragmatik fungsi thema sering bergantung pada konteks dan situasi. Dalam contoh bangun bahasa berikut, bagian manakah yang ditegaskan sebagai thema.

(5) A: Di mana kaubeli buku itu.

B: Buku itu kubeli di Toko Buku Sastra.

(6) A: Apa (yang) kaubeli di Toko Buku Sastra?

B: Buku itu (yang) kubeli di Toko Buku Sastra.

Kalimat (5A) menanyakan sesuatu tentang buku tertentu, sedangkan (5B) menceritakan sesuatu tentang buku tersebut: bagian buku itu merupakan thema yang diterangkan oleh kalimat itu. Dalam kalimat (5A) bagian buku itu merupakan titik tolak untuk memberitahukan informasi oleh pembicara kepada 
pendengar (sesuatu yang telah diketahui kepada sesuatu yang baru). Sebaliknya, (5B) memberitahukan informasi baru oleh pembicara kepada pendengar (sesuatu yang baru kepada sesuatu yang telah diketahui).

Agar dapat digunakan sebagai alat analisis atas berbagai aspek bahasa dan penggunaan bahasa, maka TBF berupaya sekaligus untuk memaksimalkan tingkat kecukupan tipologis dan meminimalkan tingkat abstraksi analisis linguistiknya. Upaya ini dilakukan dengan mengurangi tingkat abstraksi (aturan, cara kerja, atau prosedur), sehingga jarak antara struktur yang dipostulasikan dalam suatu bahasa tertentu berdasarkan teori ini dengan ungkapan-ungkapan kebahasaan aktual yang disusun dengan menggunakan terma-terma struktur ini dapat dipersempit. Pembatasan abstraksi dilakukan dengan mengikuti prinsip-prinsip berikut:

1. Menghindari transformasi (dalam arti operasi perubahan struktur);

2. Menghindari elemen-elemen kosong dalam struktur utama yang tidak mendapatkan ekspresi;

3. Menolak perangkat penyaring (filter devices);

4. Tidak menerapkan dekomposisi leksikal yang abstrak (sebagai gantinya, relasi semantik antarkata dilakukan melalui definisi makna.)

\section{PENUTUP}

Berdasarkan dari pembahasan pada Bab sebelumnya tentang teori linguistik fungsional, maka penulis dapat menyimpulkan beberapa hal sebagai berikut :

1. Linguistik fungsional dipelopori oleh Roman Jakobson dan Andre Martinet, kehadirannya sangat berarti dalam upaya menjembatani kesenjangan antara linguistik struktural Amerika dan Eropa.

2. Fungsionalisme adalah gerakan dalam linguistik yang berusaha menjelaskan fenomena bahasa dengan segala manifestasinya dan beranggapan bahwa mekanisme bahasa dijelaskan dengan konsekuensi-konsekuensi yang ada kemudian dari mekanisme itu sendiri.

3. Secara umum tata bahasa fungsional adalah teori yang berusaha menjelaskan susunan bahasa alamiah dari segi fungsionalitasnya.

4. Pengembangan teori-teori TBF harus memenuhi tiga standar: Kecukupan tipologis, Kecukupan pragmatis, Kecukupan psikologis

5. Dalam TBF ada tiga tingkatan fungsi yang menjadi pokok perhatian, yaitu: Fungsi Semantik (Pelaku [Agent], Pasien [Patient], Penerima [Recipient], dsb.). Fungsi Sintaktik (Subjek, predikat dan Objek). Fungsi Pragmatik (Tema dan Ekor [Tail], Topik dan Fokus).

6. Kemudian penerapan fungsi bahasa menurut Jakobson dapat kita aplikasikan dalam analisis wacana baik berupa teks maupun non-teks. Penerapan aliran fungsional dalam bahasa Indonesia tidak 
sepenuhnya dapat diterima. Selain adanya konsep bahasa yang berbeda, namun juga sulit mencari padanan istilah dalam bahasa Indonesia. Namun demikian aliran ini sangat mempengaruhi dalam perkembangan tata bahasa bahasa Indonesia.

\section{DAFTAR PUSTAKA}

Amanto, B. S., Umanailo, M. C. B., Wulandari, R. S., Taufik, T., \& Susiati, S. (2019). Local Consumption Diversification. Int. J. Sci. Technol. Res, 8(8), 1865-1869.

Amri, M., Tahir, S. Z. A. B., \& Ahmad, S. (2017). The Implementation of Islamic Teaching in Multiculturalism Society: A Case Study at Pesantren Schools in Indonesia. Asian Social Science, 13(6), 125.

Andini, K. NILAI BUDAYA SUKU BAJO SAMPELA DALAM FILM THE MIRROR NEVER LIES KARYA KAMILA ANDINI.

ARYANA, A. PERBANDINGAN GAYA BAHASA DALAM NOVEL ATHEIS KARYA ACHDIAT KARTA MIHARDJA DAN NOVEL TELEGRAM KARYA PUTU WIJAYA: TINJAUAN STILISTIKA.

Azwan, A. (2018). Politeness strategies of refusals to requests by Ambonese community. LINGUA: Jurnal Bahasa, Sastra, Dan Pengajarannya, 15(1), 1-6.

Bin-Tahir, S. Z., Atmowardoyo, H., Dollah, S., Rinantanti, Y., \& Suriaman, A. (2018). MULTILINGUAL AND MONO-MULTILINGUAL STUDENTS'PERFORMANCE IN ENGLISH SPEAKING. Journal of Advanced English Studies, 1(2), 32-38.

Bin Tahir, S. Z. (2017). Multilingual teaching and learning at Pesantren Schools in Indonesia. Asian EFL Journal, 89, 74-94.

Bin Tahir, S. Z. (2015). The attitude of Santri and Ustadz toward multilingual education at Pesantren. International Journal of Language and Linguistics, 3(4), 210-216.

Bin-Tahir, S. Z., \& Rinantanti, Y. (2016). Multilingual lecturers' competence in english teaching at the university of Iqra Buru, Indonesia. Asian EFL Journal, 5, 79-92.

Bin-Tahir, S. Z., Saidah, U., Mufidah, N., \& Bugis, R. (2018). The impact of translanguaging approach on teaching Arabic reading in a multilingual classroom. ljaz Arabi Journal of Arabic Learning, 1(1).

Bin-Tahir, S. Z., Bugis, R., \& Tasiana, R. (2017). Intercultural Communication of a Multicultural Family in Buru Regency. Lingual: Journal of Language and Culture, 9(2), 8.

Djamudi, N. L., Nurlaela, M., Nazar, A., Nuryadin, C., Musywirah, I., \& Sari, H. (2019, October). Alternative social environment policy through educational values in Kafi'a's customary speech to the kaledupa community of Wakatobi Island, Indonesia. In IOP Conference Series: Earth and Environmental Science (Vol. 343, No. 1, p. 012118). IOP Publishing. 
Djunaidi, F. G., Azwan, A. Y. T., Iye, R., \& bin Tahir, S. Z. Decks Range Gola Village Community Begun District Buton District North.

Indonesia, K. K. D. B. Morfologi Bahasa Indonesia.

Iye, R., \& Susiati, S. (2018). NILAI EDUKATIF DALAM NOVEL SEBAIT CINTA DI BAWAH LANGIT KAIRO KARYA MAHMUD JAUHARI ALI (Educative Values in Sebait Cinta di Bawah Langit Kairo by Mahmud Jauhari Ali). Sirok Bastra, 6(2), 185-191.

Iye, R. (2018). Tuturan emosi mahasiswa kota baubau dalam ranah demonstrasi.

Iye, R., Susiati, S., \& Karim, K. (2020). Citra Perempuan dalam Iklan Sabun Shinzui. Sang Pencerah: Jurnal IImiah Universitas Muhammadiyah Buton, 6(1), 1-7.

Iye, R. (2018). Tuturan dalam Prosesi Lamaran Pernikahan di Tomia Kabupaten Wakatobi. Jurnal Totobuang, 6(2).

Iye, R. H. NILAI-NILAI MORAL DALAM TOKOH UTAMA PADA NOVEL SATIN MERAH KARYA BRAHMANTO ANINDITO DAN RIE YANTI. TELAGA BAHASA,(7), 2, 195-206.

Iye, R. WRITING SKILLS IN SMP USWATUN HASANAH, BURU DISTRICT.

Iye, R. Jl Prof Dr HAR Basalamah No, and Namlea-Kab Buru.". TUTURAN DALAM PROSESI LAMARAN PERNIKAHAN DI TOMIA KABUPATEN WAKATOBI." Kontemporer. Bandung: PT Remaja.

Karim, K., Maknun, T., \& Abbas, A. (2019). Praanggapan Dalam Pamflet Sosialisasi Pelestarian Lingkungan Di Kabupaten Wakatobi. Jurnal IImu Budaya, 7(2), 241-247.

Mansyur, F. A., \& Suherman, L. A. (2020). The Function of Proverbs as Educational Media: Anthropological Linguistics on Wolio Proverbs. ELS Journal on Interdisciplinary Studies in Humanities, $3(2), 271-286$.

Rahayaan, I., Azwan, A., \& Bugis, R. (2016). The Students' Writing Ability through Cooperative Script Method. Jurnal Retemena, 2(2).

Sadat, A., Nazar, A., Suherman, L. O. A., Alzarliani, W. O. D., \& Birawida, A. B. (2019, October). Environmental care behavior through e-jas model with science edutainment approach. In IOP Conference Series: Earth and Environmental Science (Vol. 343, No. 1, p. 012126). IOP Publishing.

Sadat, A., Sa'ban, L. M. A., Suherman, L. O. A., Bahari, S., Ibrahim, T., \& Zainal, M. (2019, October). Internalization characters of environmental care and disaster response through care partner schools. In IOP Conference Series: Earth and Environmental Science (Vol. 343, No. 1, p. 012125). IOP Publishing.

Salamun, T. (2018). DEIKSIS PERSONA BAHASA INDONESIA DIALEK AMBON [Personal Deixes of Indonesian Leanguage With Ambonese Dialect]. Totobuang, 5, 325-339. 
Salamun, T. (2018). RELASI KEKERABATAN BAHASA HITU, WAKAL, MORELA, MAMALA, DAN HILA DI PROVINSI MALUKU [The Family Relationship Language Hitu, Wakal, Morela, Mamala, and Hila in Maluku Province].

Suherman, L. A. (2018). The Analysis of Metaphorical Domain on English "Stab Verb" in Corpora. ELS Journal on Interdisciplinary Studies in Humanities, 1(1), 52-58.

Suherman, L. O. A., Salam, S., Mursanto, D., Efendi, A., Bahar, S. B., \& Kanna, T. (2019, October). The effect of open-air curing on compressive strength of geopolymer mortar containing laterite soil and slaked lime. In IOP Conference Series: Earth and Environmental Science (Vol. 343, No. 1, p. 012133). IOP Publishing.

Susiati, S., \& lye, R. (2018). Kajian Geografi Bahasa dan Dialek di Sulawesi Tenggara: Analisis Dialektometri. Gramatika: Jurnal Ilmiah Kebahasaan dan Kesastraan, 6(2), 137-151.

Susiati, S., lye, R., \& Suherman, L. O. A. (2019). Hot Potatoes Multimedia Applications in Evaluation of Indonesian Learning In SMP Students in Buru District. ELS Journal on Interdisciplinary Studies in Humanities, 2(4), 556-570.

Susiati, S. (2018). Homonim bahasa kepulauan tukang besi dialek kaledupa di kabupaten wakatobi [the homonymon of tukang besi island languange in kaledupa dialect at wakatobi regency]. Totobuang, 6 (1), 109, 123.

Susiati, S. (2020). Emosi Verbal Suku Bajo Sampela.

Susiati, S. (2020). Fenomena Tuturan Emosi Verbal Bahasa Indonesia Suku Bajo Sampela.

Susiati, S. (2020). Nilai Budaya Suku Bajo Sampela Dalam Film The Mirror Never Lies Karya Kamila Andini.

Susiati, S. (2020). Konsep Pertentangan Dalam Film" Aisyah Biarkan Kami Bersaudara" Karya Herwin Novianto.

Susiati, S. (2020). Strategi AMBT untuk Meningkatkan Kemampuan Membaca Pemahaman Interpretatif Siswa Kelas IV SD Negeri 3 Namlea Kabupaten Buru.

Susiati, S. (2020). Fungsi Konatif Pada Iklan Mesin Cuci Hole-Less Tub Dari Sharp: Analisis Wacana Kritis.

Susiati, S. (2020). GAYA BAHASA SECARA UMUM DAN GAYA BAHASA PEMBUNGKUS PIKIRAN.

Susiati, S. (2020). The Concept Of Togetherness In The Films" Aisyah Biarkan Kami Bersaudara" By Herwin Novianto.

Susiati, S. (2020). Konsep Kebersamaan Dalam Film" Aisyah Biarkan Kami Bersaudara" Karya Herwin Novianto.

Susiati, S. (2020). Teori dan Aliran Linguistik: Tata Bahasa Generatif. 
Susiati, S. (2020). Metode Pembelajaran Bahasa Indonesia: Sosiodrama.

Susiati, S. (2020). Rekontruksi Internal Bahasa Bugis dan Bahasa Makassar: Linguistik Komparatif.

Susiati, S. Bahan Ajar: Psikolinguistik.

Susiati, S. (2020). PENTINGNYA MELESTARIKAN BAHASA DAERAH.

Susiati, S. (2020). Morfologi Kelas Kata Dalam Bahasa Indonesia.

Susiati, S. (2020). Semantik: Teori Semantik, Relasi Makna, Marked, Dan Unmarked.

Susiati, Y. T. Risman Iye. A. Kesantunan Imperatif Bahasa Indonesia Suku Bajo Sampela: Balai Pembinaan dan Pengembangan Bahasa. 2018. Kongres Bahasa Indonesia (No. 12, pp. 1-6). Report.

Susiati, S. (2020). Kesantunan Imperatif Bahasa Melayu Ambon.

Susiati, S. (2020). Gaya Bahasa Secara Umum Dan Gaya Bahasa Pembungkus Pikiran: Stilistika.

Susiati, S. (2020). Tuturan Kesantunan Imperatif Bahasa Indonesia Suku Bajo Sampela.

Susiati, S. (2020). Nilai Budaya Suku Bajo Sampela Dalam Film The Mirror Never Lies Karya Kamila Andini.

Susiati, S. (2020). Pengaplikasian Multimedia Hot Potatoes Dalam Evaluasi Pembelajaran Bahasa Indonesia Pada Siswa SMP Negeri 9 Buru.

Susiati, S., \& Iye, R. (2018). Kajian Geografi Bahasa dan Dialek di Sulawesi Tenggara: Analisis Dialektometri. Gramatika: Jurnal IImiah Kebahasaan dan Kesastraan. 6 (2), 137-151.

Susiati, S. (2020). Kaidah Fonologi Bahasa Indonesia.

Susiati, S. (2020). Wujud Morfologi Bahasa Indonesia.

Susiati, S. (2020). Makian Bahasa Wakatobi Dialek Kaledupa.

Susiati, S. (2020). Eksistensi Manusia Dalam Film" Aisyah Biarkan Kami Bersaudara" Karya Herwin Novianto.

Susiati, S. NILAI BUDAYA SUKU BAJO SAMPELA DALAM FILM THE MIRROR NEVER LIES.

Susiati, S. (2020). Konsep Keterasingan Dalam Film" Aisyah Biarkan Kami Bersaudara" Karya Herwin Novianto.

Susiati, S. (2020). Concept Of Conflict In The Films "AISYAH BIARKAN KAMI BERSAUDARA" By Herwin Novianto.

Susiati, S. (2020). Embrio Nasionalisme Dalam Bahasa dan Sastra.

Susiati, S. PERWUJUDAN SIMILE OLEH MERARI SIREGAR DALAM NOVEL AZAB DAN SENGSARA. 
Susiati, S. (2020). Nilai Pembentuk Karakter Masyarakat Wakatobi Melalui Kabhanti Wa Leja.

Tahir, S. Z. A. B. (2017). Pengembangan Materi Multibahasa untuk Siswa Pesantren. Unpublish dissertation.

Tahir, S. Z. B. (2015). Multilingual Teaching And Learning At Pesantren. 14 Asian EFL Journal Conference.

Tenriawali, A. Y. (2018). Representasi korban kekerasan dalam teks berita daring tribun timur: analisis wacana kritis [the representation victims of violence in tribun timur online news text: critical discourse analysis]. TOTOBUANG, 6 (1), 1, 15.

Yusdianti, A. (2020). THE REPRESENTATION VICTIMS OF VIOLENCE IN TRIBUN TIMUR ONLINE NEWS TEXT: CRITICAL DISCOURSE ANALYSIS. 